\title{
Analisis Kinerja Raspberry Pi Sebagai SIP Server Untuk Aplikasi Video Phone
}

\author{
Performance Analysis Of Raspberry Pi as SIP Server for Video Phone Application
}

\author{
Suharsono Bantun ${ }^{1}$, Ahmad Ashari², Rahmat Karim ${ }^{3}$ \\ 1,3 Jurusan Sistem Informasi, FTI Universitas Sembilanbelas November Kolaka, Kolaka \\ ${ }^{2}$ Jurusan Ilmu Komputer dan Elektronika, FMIPA UGM, Yogyakarta \\ E-mail: ${ }^{1}$ suharsonob@usn.ac.id, ${ }^{2}$ ashari@ugm.ac.id, ${ }^{3}$ rahmatkarim@usn.ac.id
}

\begin{abstract}
Abstrak
Munculnya Single Board Computer seperti Raspberry Pi di pasaran yang lebih murah serta hemat daya dibandingkan PC dapat menghemat biaya pengadaan komputer dan biaya operasional. Dengan kemampuan komputasi yang dimilikinya, Raspberry Pi dapat difungsikan menjadi berbagai macam server termasuk server VVoIP, sehingga untuk membangun jaringan VVoIP tidak lagi diperlukan sebuah komputer. Dalam penelitian ini Raspberry Pi difungsikan sebagai SIP (Session Initiation Protocol) server dari aplikasi video phone menggunakan Asterisk. Penelitian ini bertujuan untuk mengetahui kinerja Raspberry Pi baik dalam panggilan per detik maupun panggilan bersamaan dengan resolusi CIF dan resolusi VGA. Penelitian ini juga menggunakan codec G711a dan VP8, serta untuk mengetahui kelayakan penggunaan server tersebut, dilakukan analisis QoS dari setiap panggilan dengan jumlah panggilan bersamaan tertentu. Untuk perbandingan, akan dilakukan pengujian terhadap PC yang digunakan sebagai SIP server. Berdasarkan hasil pengujian, dapat dilihat bahwa untuk jumlah panggilan per detik dan panggilan bersamaan, Raspberry Pi mampu melayani komunikasi VVoIP dengan baik dan layak diimplementasikan sebagai SIP server untuk aplikasi video phone. Namun, untuk penggunaan pada skala yang lebih besar, PC masih memiliki lebih banyak keunggulan dibanding Raspberry. Raspberry Pi yang difungsikan sebagai SIP server mampu melayani hingga 131 panggilan video dengan resolusi CIF dan 94 panggilan video dengan resolusi VGA.
\end{abstract}

Kata kunci: Asterisk, QoS, Raspberry, SIP (Session Initiation Protocol), VVoIP

\begin{abstract}
Single Board Computer like Raspberry Pi is cheaper and more power-efficient than PC and it can save the cost of computer procurement and the cost of operating. The capability of Raspberry $P i$ can be enabled into a variety of servers including VVoIP servers. Thus, creating VVoIP network is no longer needed a computer. In this research, Raspberry Pi is functioned as SIP (Session Initiation Protocol) a server from video phone application using Asterisk. This research aims to determine the performance of Raspberry Pi as SIP server both in terms of call per second and concurrent calls with CIF and VGA resolution. This research also uses G711a and VP8 codec. In order to know the feasibility of using this server, the researcher did a QoS analysis each call will be employed. For comparison, we will conduct a test on PC which was used as server SIP. Based on the experiment results, it can be seen that for the number of calls per second and concurrent calls, Raspberry Pi is able to serve VVoIP communication properly and is feasible to be implemented as a SIP server for video phone applications. However, for use on a larger scale, the PC still has more advantages compared to Raspberry. Raspberry Pi can serve up to 131 of video call with CIF resolution (352x288) and 94 video calls with VGA resolution (640x480).
\end{abstract}

Keywords: Asterisk, QoS, Raspberry, SIP (Session Initiation Protocol), VVoIP 


\section{PENDAHULUAN}

Teknologi internet telah mengubah cara orang berkomunikasi secara continuous. Dengan media kabel dan nirkabel penggunaan internet dari public switched telephone network (PSTN) untuk mengirimkan data telah menjadi pilihan yang lebih menguntungkan karena biaya rendah dan layanannya [1]. Pertumbuhan aplikasi suara dan video telah sangat meningkat. Sebagai standar baru Voice and Video over Internet Protocol (VVoIP) telah menjadi standar yang ideal untuk aplikasi suara dan video di internet. Selain itu, dengan adanya ponsel, pengguna dapat melakukan panggilan suara dan video melalui internet kapan pun dan di mana pun yang mereka ingin dengan kualitas yang lebih baik dan dengan biaya yang lebih rendah dari pada public switched telephone network (PSTN)[2].

Sejauh ini panggilan video dipengaruhi pada kualitas jaringan yang akan mempengaruhi kualitas panggilan video, seperti perbedaan bandwidth dan packet loss karena panggilan video membutuhkan komunikasi real time antara pengguna[3]. Selain itu menurut Zasćpa dkk [4], untuk memilih platform PC atau server yang baik dari segi harga maupun kinerja merupakan persoalan utama dalam membangun jaringan VoIP. Kinerja server yang kurang baik akan menurunkan kualitas atau bahkan tidak mampu untuk menghubungkan antar user. Kinerja server akan mempengaruhi jumlah panggilan masuk yang mampu dilayani serta berpengaruh dalam Quality of Service jadi di asumsikan bahwa pada VVoIP juga permasalahan utamanya ada pada pemilihan platform PC atau server yang cocok.

Aplikasi asterisk memungkinkan untuk di install di berbagai Single Board Computer yang lebih murah serta hemat daya. Terdapat banyak Single Board Computer yang muncul di pasaran diantaranya adalah Raspberry Pi, Beagle board, Banana Pi, PC Duino, Cubie board, Udo, Odroid. Menurut Najihi [5] hal ini akan menghemat biaya pengadaan komputer dan biaya operasional. Raspberry Pi menurut Najihi [5] dapat difungsikan menjadi berbagai macam server termasuk server VoIP, sehingga untuk membangun jaringan VoIP tidak lagi diperlukan sebuah komputer.

Raspberry Pi menurut Najihi [5] merupakan sebuah komputer mini berukuran kecil yang memiliki kemampuan komputasi yang sangat bagus. Awalnya diciptakan untuk pendidikan namun dalam perkembangannya banyak yang menggunakan komputer mini ini untuk bereksperimen termasuk sebagai server. Menurut Prapanca [6] Raspberry Pi dilengkapi dengan video core 4 GPU yang mampu memutar video dengan kualitas bluray sehingga ini menjadi alasan mendasar memilih Raspberry Pi sebagai server karena kemampuannya dalam memutar video high definition. Selain itu Raspberry Pi sangat populer sehingga mudah didapatkan dan banyak dukungan dari komunitas dan pengembang software dari sistem operasi. Raspberry Pi dapat dikembangkan menjadi banyak kegunaan dalam dunia komputer. Konsumsi daya Raspberry Pi sangat rendah yang sangat berguna untuk membuat aplikasi mobile yang hemat energi. Kinerjanya menjadi lebih rendah dibandingkan komputer untuk dijadikan server [5].

Penelitian mengenai perancangan dan analisis kinerja dari Single Board Computer pernah dilakukan oleh Najihi [5] pada penelitian tersebut merancangan kemudian menganalisis server VoIP dengan codec suara GSM dan G711 menggunakan Raspberry Pi 2 Model B dari penelitian tersebut didapatkan Raspberry Pi 2 Model B layak diimplementasikan sebagai server dan mampu melayani komunikasi VoIP (Voice over Internet Protocol) dengan baik pada jumlah panggilan tertentu. Najwaini [7] juga melakukan penelitian tentang perancangan dan analisis VoIP (Voice over Internet Protocol) dengan codec suara GSM dan G711 menggunakan Wireless Acces Point sebagai server penelitian tersebut dihasilkan bahwa VoIP server pada Wireless Access Point mampu melayani komunikasi VoIP (Voice over Internet Protocol) dengan baik untuk jumlah panggilan yang sedikit sehingga layak diimplementasikan untuk penggunaan skala kecil.

Penelitian mengenai perancangan dan analisis kinerja server VVoIP (Voice/Video over Internet Protocol) dengan codec G711a untuk audio dan codec VP8 untuk video menggunakan Raspberry Pi 3 Model B belum ada, maka perlu di adakan penelitian untuk mengetahuinya. Dengan mengetahui QoS (Quality of Service) dari server dapat diputuskan apakah pemanfaatan Single Board Computer khususnya pada Raspberry Pi 3 Model B sebagai server VVoIP (Voice/Video over Internet Protocol) layak untuk diimplementasikan. Pada penelitian ini akan 
dibuat sebuah SIP (Session Initiation Protocol) server dari aplikasi video phone menggunakan Asterisk yang di-install pada Single Board Computer Raspberry Pi 3 Model B kemudian dari server tersebut akan dilakukan analisis kinerja sehingga dapat diketahui berapa banyak panggilan yang mampu dilayani dengan kualitas yang baik.

\section{METODE PENELITIAN}

Ada 7 (tujuh) tahapan yang akan dilakukan peneliti. Diantaranya adalah:

\subsection{Studi Pustaka}

Tahapan ini dilakukan dengan mencari dan mempelajari bahan pustaka baik dari jurnal, digital library, buku, e-book atau karya-karya ilmiah yang berkaitan dengan Raspberry Pi, VVoIP dan Quality of Service. Pada tahap ini peneliti juga mempelajari metode-metode dari bahan pustaka yang sudah terkumpul. Hasil dari studi ini berupa daftar referensi yang akan dipakai dalam penelitian.

\subsection{Analisis Kebutuhan Pengujian}

Analisis kebutuhan pengujian bertujuan untuk mengidentifikasi kebutuhan sebelum melakukan analisis kinerja Raspberry Pi yang meliputi kebutuhan perangkat keras dan kebutuhan perangkat lunak.

1. Analisis kebutuhan perangkat keras

Ada beberapa macam kebutuhan perangkat keras yang akan digunakan termasuk diantaranya:

a. Raspberry Pi dengan spesifikasi yang dapat dilihat pada Tabel 1 .

Tabel 1. Spesifikasi Raspberry Pi

\begin{tabular}{|l|l|}
\hline CPU & ARM Cortex-A53 Broadcom BCM2837 \\
\hline CPU Speed & 1.2 GHz 64-bit quad-core \\
\hline GPU & Broadcom Video Core IV @ 250 MHz (BCM2837: 3D part of GPU @ 300 MHz, video part of \\
& GPU @ 400 MHz) \\
& MPEG-2 and VC-1 (with license),[48] 1080p30 \\
\hline RAM size & 1 GB (shared with GPU) \\
\hline On-Board network & $10 / 100$ Mbit/s Ethernet, 802.11n wireless, Bluetooth 4.1 \\
\hline
\end{tabular}

\section{b. Notebook}

Pada penelitian ini digunakan tiga buah notebook, notebook digunakan sebagai client SIP (Session Initiation Protocol). satu buah notebook sebagai client SIP (Session Initiation Protocol) pada softphone Linphone dan Jitsi, dua buah notebook sebagai User Agent Client $(U A C)$ dan User Agent Server (UAS). Tabel 2 menunjukkan spesifikasi notebook yang digunakan dalam penelitian ini.

Tabel 2 Spesifikasi notebook

\begin{tabular}{|l|l|l|l|}
\hline Merek/Tipe & Asus A43S & Toshiba C640D & ASUS N46VJ \\
\hline CPU & Intel Core i5-2450M & Quad core AMD A4 5000 APU & Intel Core i5-3210M \\
\hline CPU Speed & $@ 2.5 \mathrm{GHz}$ & $@ 1,5 \mathrm{GHz}$ & @2,5 GHz \\
\hline RAM & DDR3 6 GB & DDR3 2 GB & DDR3 8 GB \\
\hline Hardisk & $640 \mathrm{~GB}$ & $500 \mathrm{~GB}$ & $750 \mathrm{~GB}$ \\
\hline Operating System & Windows 10 & Ubuntu Desktop 16.04 & Ubuntu Desktop 16.04 \\
\hline Penggunaan & $\begin{array}{l}\text { SIP client Linphone } \\
\text { dan Jitsi }\end{array}$ & $\begin{array}{l}\text { sebagai User Agent Server } \\
(U A S)\end{array}$ & $\begin{array}{l}\text { sebagai User Agent Client } \\
\text { (UAC) }\end{array}$ \\
\hline
\end{tabular}


c. Fast Ethernet Switch dengan merek TP-Link TL-SG1016D. Switch ini memiliki 16 port Ethernet dengan maksimal kecepatan 1000 mbps. Switch ini digunakan untuk menghubungkan alat ke jaringan.

2. Analisis kebutuhan perangkat lunak

Perangkat lunak yang dibutuhkan dalam implementasi pada penelitian ini dijelaskan pada Tabel 3.

Tabel 3 Spesifikasi perangkat lunak

\begin{tabular}{|l|l|}
\hline Operating System & RasPBX, Windows 10 Education dan Ubuntu 16.04. Trixbox 2.8 \\
\hline Server VVoIP & Asterisk \\
\hline Software Phone & Jitsi dan Linphone \\
\hline Call generator & SIPp \\
\hline Tools monitoring & Sar dan Wireshark \\
\hline
\end{tabular}

\subsection{Perancangan Sistem Pengujian}

Perancangan sistem pengujian dilakukan setelah semua kebutuhan didapatkan melalui tahap analisis kebutuhan yang meliputi kebutuhan perangkat keras dan perangkat lunak. Setelah kebutuhan untuk menguji kinerja Raspberry Pi terpenuhi selanjutnya adalah konfigurasi perangkat keras dan konfigurasi perangkat lunak. Alur konfigurasi sebelum melakukan pengujian secara umum akan ditunjukkan pada Gambar 1.

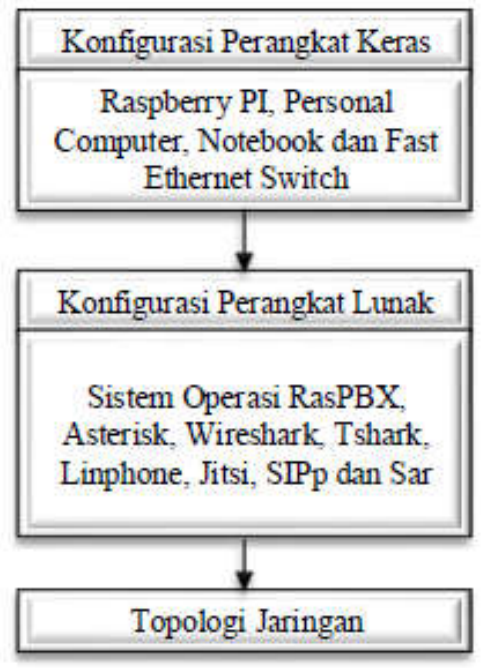

Gambar 1 Alur perancangan sistem pengujian secara umum

Pada Gambar 1 dijelaskan mengenai alur perancangan sistem pengujian secara umum, dimulai dari konfigurasi perangkat keras yang terdiri dari Raspberry Pi, Notebook dan Fast Ethernet Switch. Setelah konfigurasi perangkat keras selesai dilakukan, kemudian melakukan konfigurasi perangkat lunak yang terdiri dari Sistem Operasi RasPBX agar Raspberry Pi dapat berfungsi sebagai SIP (Session Initiation Protocol) server, Asterisk yang berfungsi untuk menangani pensinyalan SIP (Session Initiation Protocol), Wireshark digunakan untuk mengamati Quality of Service pada jaringan, Aplikasi Linphone dan Jitsi digunakan untuk menganalisa kualitas komunikasi video, SIPp digunakan untuk membangkitkan panggilan dan aplikasi Sar yang dapat menampilkan load processor.

Pada umumnya suatu sistem pengujian harus memiliki suatu masukan, proses dan keluaran. Sebagaimana yang ditunjukkan pada Gambar 2 yang berfungsi sebagai masukan adalah input network traffic. Raspberry Pi, notebook dan Fast Ethernet Switch sebagai pemroses yang memproses aliran data, mengirim dan menerima serta menghasilkan output analisis jumlah panggilan perdetik, jumlah panggilan bersamaan serta performance Quality of Service. 


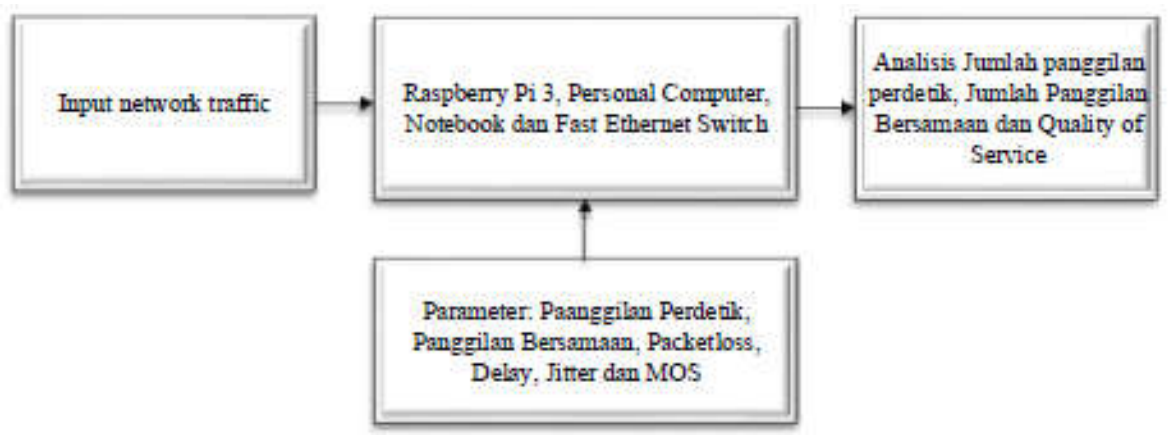

Gambar 2 Diagram blok sistem pengujian

\subsection{Implementasi}

Setelah melakukan perancangan perangkat keras dan perangkat lunak, selanjutnya dibuat perancangan topologi jaringan untuk pengujian. Topologi jaringan yang dibuat dapat dilihat pada Gambar 3. Gambar 3 merupakan topologi jaringan yang akan digunakan dalam penelitian ini. Perangkat yang digunakan yaitu tiga buah notebook dengan satu notebook menggunakan dua buah Ethernet, dua buah notebook lainnya masing-masing menggunakan satu buah Ethernet, satu buah perangkat switch dan satu buah Raspberry Pi.
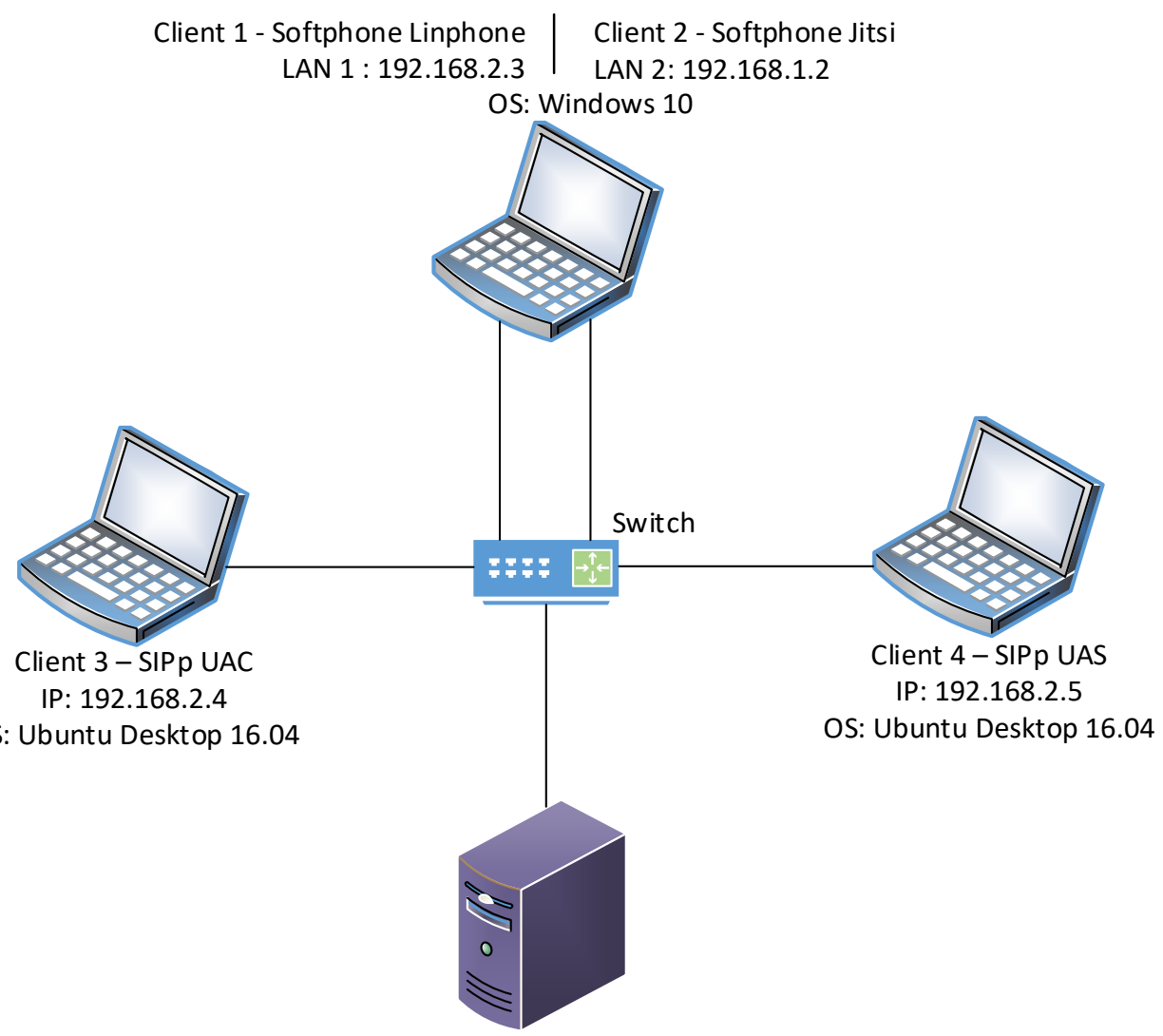

Raspberry/SIP server

eth0 : 192.1.168.1.1

eth0 1: 192.168.2.2

OS: Raspbx

Gambar 3 Topologi Jaringan

Pada tahap implementasi ini juga akan dilakukan implementasi sistem pengujian dari hasil analisis dan perancangan sistem pengujian yang telah dilakukan untuk uji kinerja Raspberry Pi sebagai server, adapun implementasinya yaitu membangun SIP (Session Initiation Protocol) 
server pada Raspberry Pi berbasiskan sistem operasi RasPBX dan melakukan berbagai konfigurasi dan pembuatan call generator untuk menguji kinerja Raspberry Pi dalam melakukan panggilan.

\subsection{Uji kinerja}

Setelah sistem pengujian dipersiapkan, proses selanjutnya adalah melakukan pengujian kinerja, menurut Najwaini [7] dan [5] Najihi untuk mengetahui kinerja server ada 3 cara yaitu:

1. Pengujian panggilan perdetik

Pengujian jumlah maksimum panggilan perdetik merupakan banyaknya permintaan pembangunan hubungan (panggilan) yang mampu di proses oleh server dalam setiap detik. Call generator SIPp dilakukan pada pengujian ini. Pengujian ini dilakukan dengan cara satu buah notebook ada yang sebagai pemanggil (UAC) dan notebook lainnya ada yang sebagai penerima panggilan (UAS). Panggilan dilakukan dengan rate panggilan tertentu yang ditingkatkan sampai server tidak mampu lagi melayani panggilan yang datang. Untuk proses pengujian panggilan per detik dapat dilihat pada Gambar 4 yang merupakan diagram alir pengujian panggilan per detik.

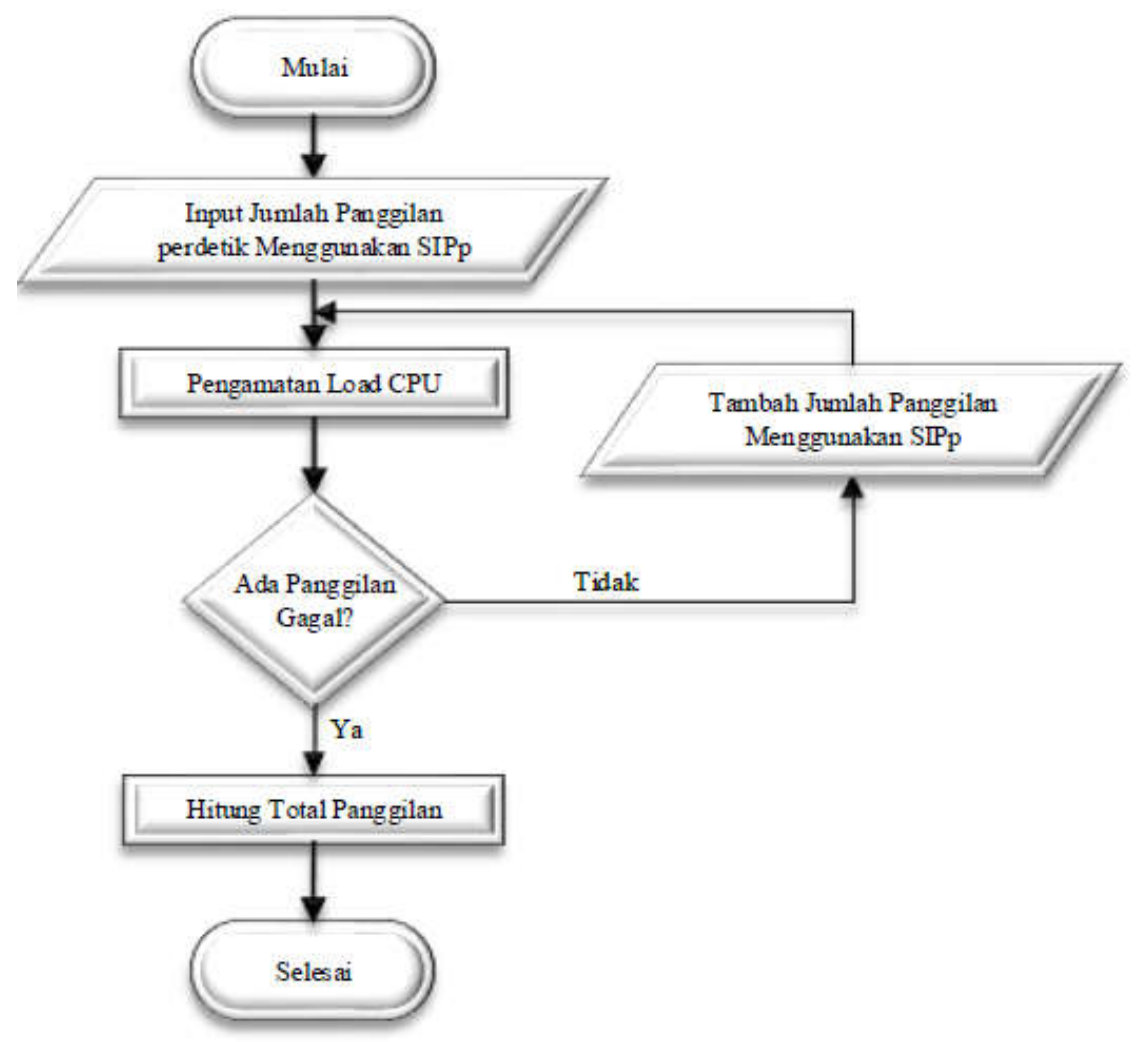

Gambar 4 Diagram alir pengujian panggilan per detik

2. Pengujian panggilan bersamaan

Pengujian jumlah maksimum panggilan bersamaan dilakukan dengan 2 resolusi video yaitu CIF (352x288) dan VGA (640x480) menggunakan softphone untuk panggilan dan SIPp untuk membangkitkan panggilan. Jumlah panggilan akan dinaikkan sampai mencapai jumlah panggilan bersamaan tertentu dan selanjutnya dilakukan pengamatan terhadap penggunaan processor. Proses pengujian panggilan bersamaan dapat dilihat pada Gambar 5. 


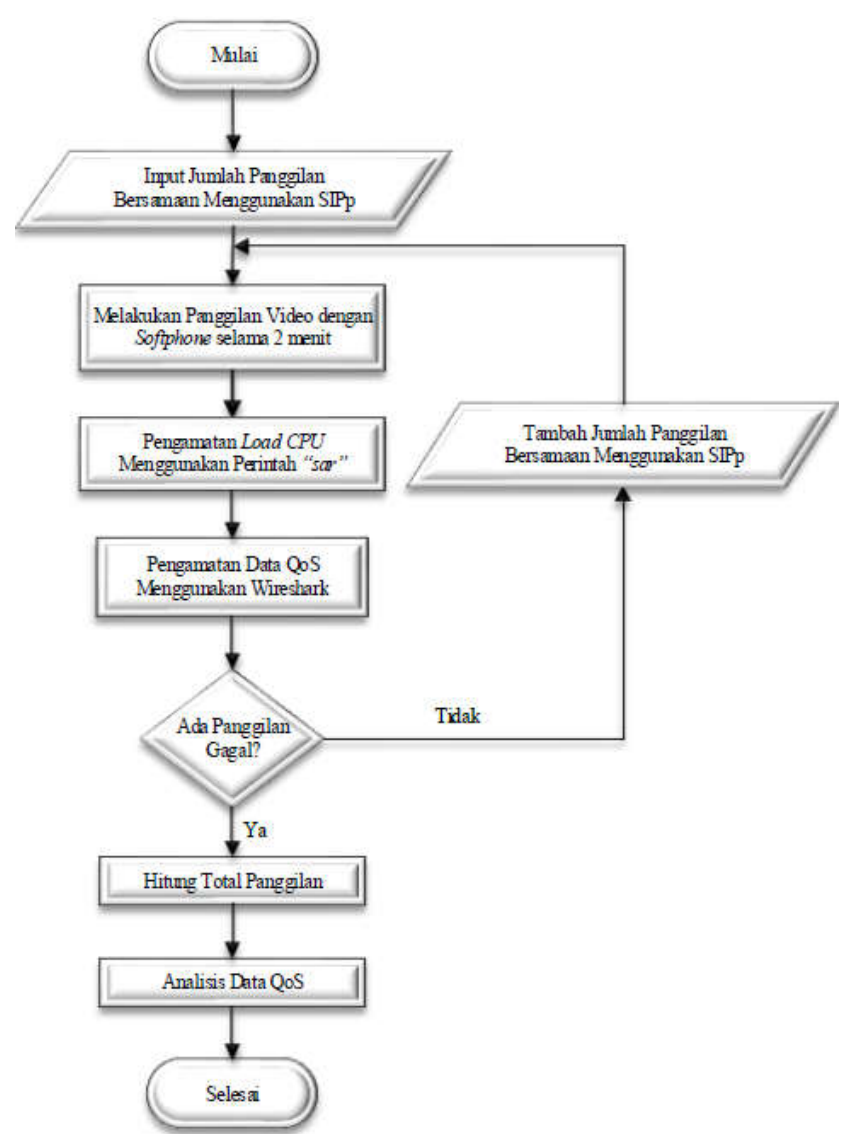

Gambar 5. Diagram alir pengujian panggilan bersamaan dan pengujian QoS

\section{Pengujian Quality of Service}

Quality of Service $(Q o S)$ dapat dikatakan sebagai suatu istilah yang digunakan untuk mendefinisikan kualitas suatu layanan (service) jaringan komputer, sehingga peneliti bisa mengetahui seberapa baik kualitas dari layanan tersebut. Dalam penelitian ini parameter QoS yang akan dianalisa adalah delay, jitter, packet loss dan Mean Opinion Score (MOS) [8]. Dalam bidang telekomunikasi Quality of Service sebagai sebuah keseluruhan kebutuhan khusus yang diberikan oleh jaringan kepada pengguna, dimana hal ini diperlukan guna mendapatkan kegunaan yang dibutuhkan dari layanan. Peter L. Dordal menjelaskan Quality of Service sebagai kepadatan jaringan yang memiliki sebuah nilai minimum tertentu dari layanan jaringan [9]. Pengujian Quality of Service dari panggilan juga menggunakan 3 buah notebook. Untuk mengcapture paket data pada panggilan bersamaan digunakan Wireshark. Prosedur pengujian ini dilakukan seperti saat pengujian jumlah maksimum panggilan bersamaan yang ditunjukkan pada Gambar 5 yaitu membangkitkan panggilan dan kemudian mencapture data yang dengan menggunakan tools monitoring jaringan (sar dan wireshark).

\subsection{Analisis data dan kesimpulan}

Hasil pengujian akan dianalisis dengan menggunakan data yang didapat dari tahap evaluasi yakni jumlah panggilan per detik, jumlah panggilan bersamaan dan Quality of Service. Analisis pada tahap ini bertujuan untuk mengetahui performance dari Raspberry Pi sebagai SIP (Session Initiation Protocol) server. Dari analisis ini peneliti dapat mengetahui performance ratarata dari masing-masing parameter yang akan diujikan. 


\section{HASIL DAN PEMBAHASAN}

\subsection{Maksimum Kedatangan Panggilan Per Detik}

Penggunaan Raspberry Pi sebagai server VVoIP tidak dapat disetarakan dengan PC, meskipun processor yang digunakan Raspberry Pi sudah mendekati processor PC. Berdasarkan pada grafik Gambar 6 dapat dilihat hasil pengujian panggilan pada PC yang dijadikan sebagai server 3 kali dari kemampuan Raspberry Pi yang dijadikan sebagai server. Pada saat 80 panggilan perdetik pada Raspberry Pi penggunaan processor mencapai $81.8 \%$ sedangkan penggunaan processor pada PC saat 80 panggilan per detik hanya sekitar $22,4 \%$.

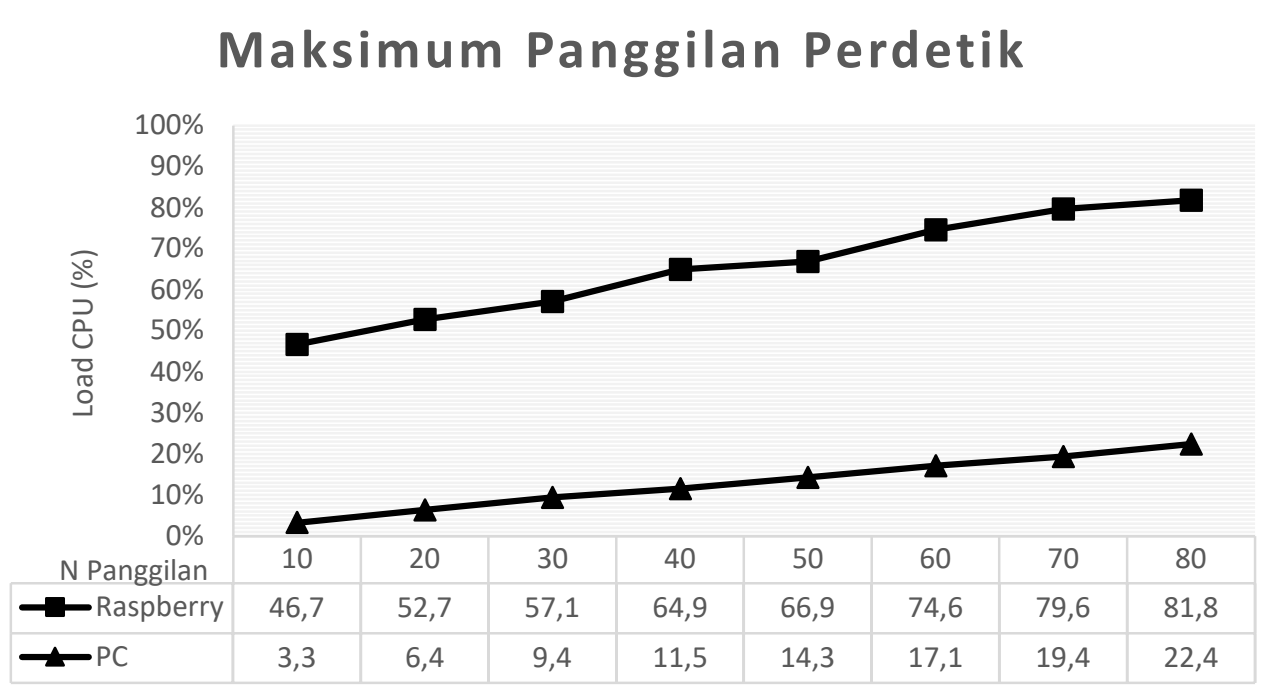

Gambar 6 Grafik maksimum kedatangan panggilan perdetik Raspberry Pi dan PC

\subsection{Maksimum Panggilan Bersamaan}

Pengujian jumlah panggilan bersamaan dilakukan terhadap 2 resolusi video yaitu CIF (352x288) dan VGA (640x480) pada grafik Gambar 7.

\section{Maksimum Panggilan Bersamaan}

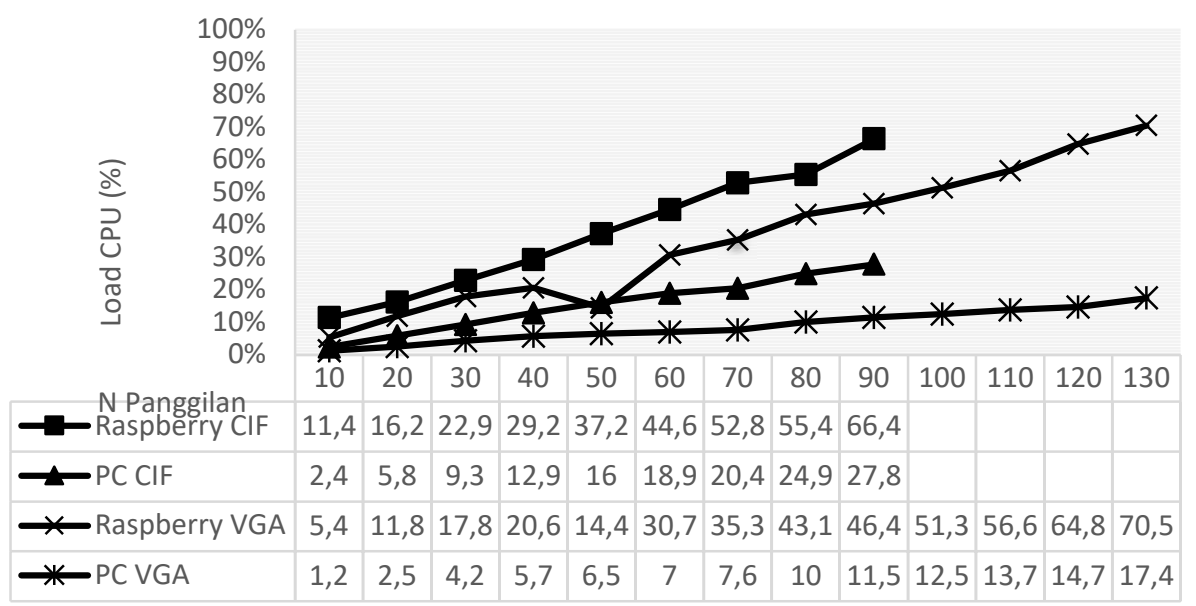

Gambar 7 Grafik maksimum panggilan bersamaan resolusi CIF 
Pada pengujian panggilan bersamaan dengan resolusi video CIF $(352 \times 288)$ dengan menggunakan PC sebagai server mampu melayani panggilan video hingga 380 panggilan secara bersamaan. Sedangkan pada panggilan bersamaan dengan resolusi video VGA (640x480), PC yang digunakan sebagai server mampu melayani hingga 260 panggilan bersamaan. Meskipun Raspberry Pi menghasilkan hasil panggilan perdetik dan panggilan bersamaan yang rendah namun kecilnya ukuran dan rendahnya daya yang dipakainya merupakan daya tarik tersendiri bagi pengguna yang mementingkan kepraktisan, kecilnya penggunaan daya, serta kesenyapan. Raspberry Pi memang lebih senyap dibandingkan komputer desktop, ini karena Raspberry Pi tidak memiliki bagian yang bergerak seperti kipas atau motor penggerak hard disk.

\subsection{Quality of Service}

Pengujian Quality of Service (QoS) dengan menganalisis tiga parameter QoS yaitu delay, jitter dan packet loss. Delay dapat didefenisikan sebagai durasi waktu dimana sesuatu terlambat atau tertahan. Dalam bidang telekomunikasi delay dapat diartikan sebagai durasi waktu keterlambatan data yang diterima dari pengirim [9]. Propagation delay dapat dijelaskan sebagai durasi waktu yang dibutuhkan sebuah paket atau data, sebagai fungsi dari kombinasi dari semua jarak transmisi dan kecepatan cahaya yang melalui media transmisi. Sedangkan queing delay adalah durasi waktu yang dibutuhkan sebuah paket untuk menunggu hingga ditransmisikan melalui media transmisi kabel maupun nirkabel. Delay rata - rata maupun variasi delay berpengaruh ketika menghasilkan sebuah selang waktu antara apakah sebuah paket dapat sampai ke tujuannya [10]. Nilai delay dan jitter pada panggilan video dengan resolusi panggilan video CIF (352x288) dan VGA (640x480) dapat dilihat pada Gambar 8 dan Gambar 9

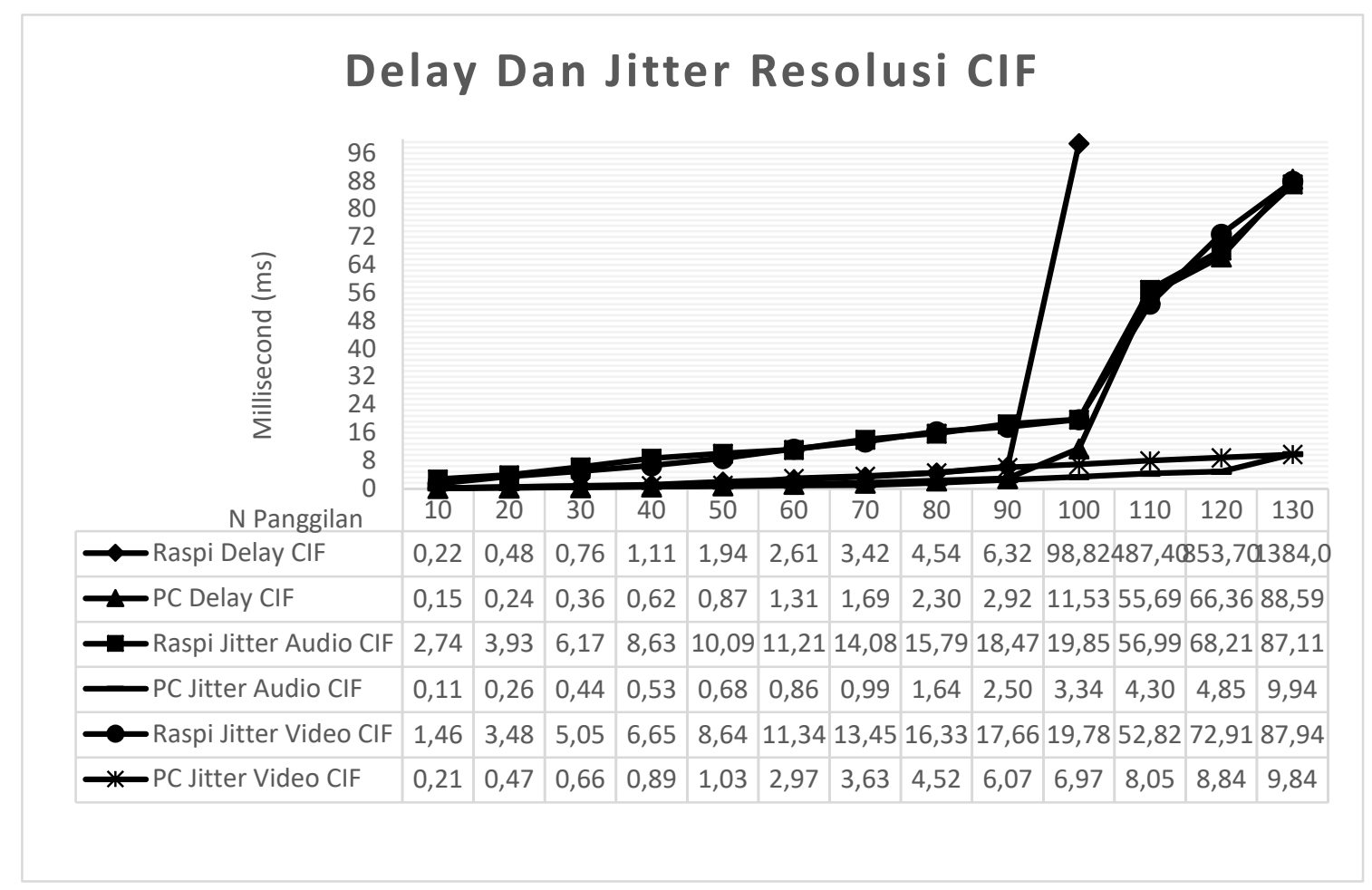

Gambar 8 Grafik Jitter dan Delay panggilan video resolusi CIF (352x288)

Nilai delay didapatkan dengan cara meng-capture dari dua buah LAN di PC dimana panggilan terjadi antara LAN 1 menuju LAN 2. Delay yang diukur adalah delay pengiriman paket 
dari LAN 1 sampai diterima LAN 2. Pada pengukuran jitter pada panggilan video bersamaan dengan resolusi CIF (352x288) dan resolusi VGA (640x480) akan dibagi menjadi 2 bagian yaitu jitter audio maupun jitter video. Nilai pengukuran packet loss panggilan video dengan resolusi video CIF (352x288) dan VGA (640x480) dapat pada Raspberry Pi dan PC dilihat berdasarkan grafik pada Gambar 10.

\section{Delay Dan Jitter Resolusi VGA}

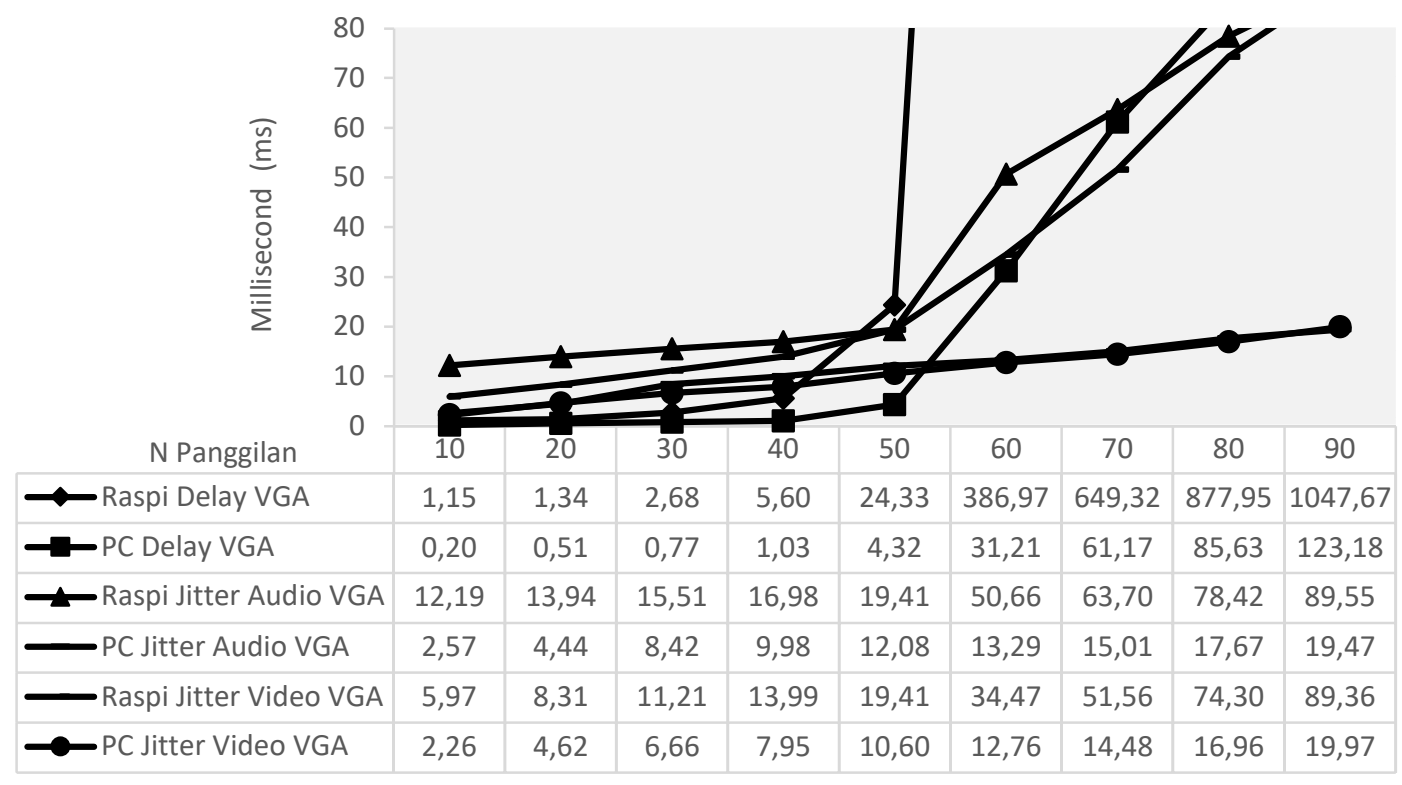

Gambar 9 Grafik Jitter dan Delay panggilan video resolusi VGA (640x480)

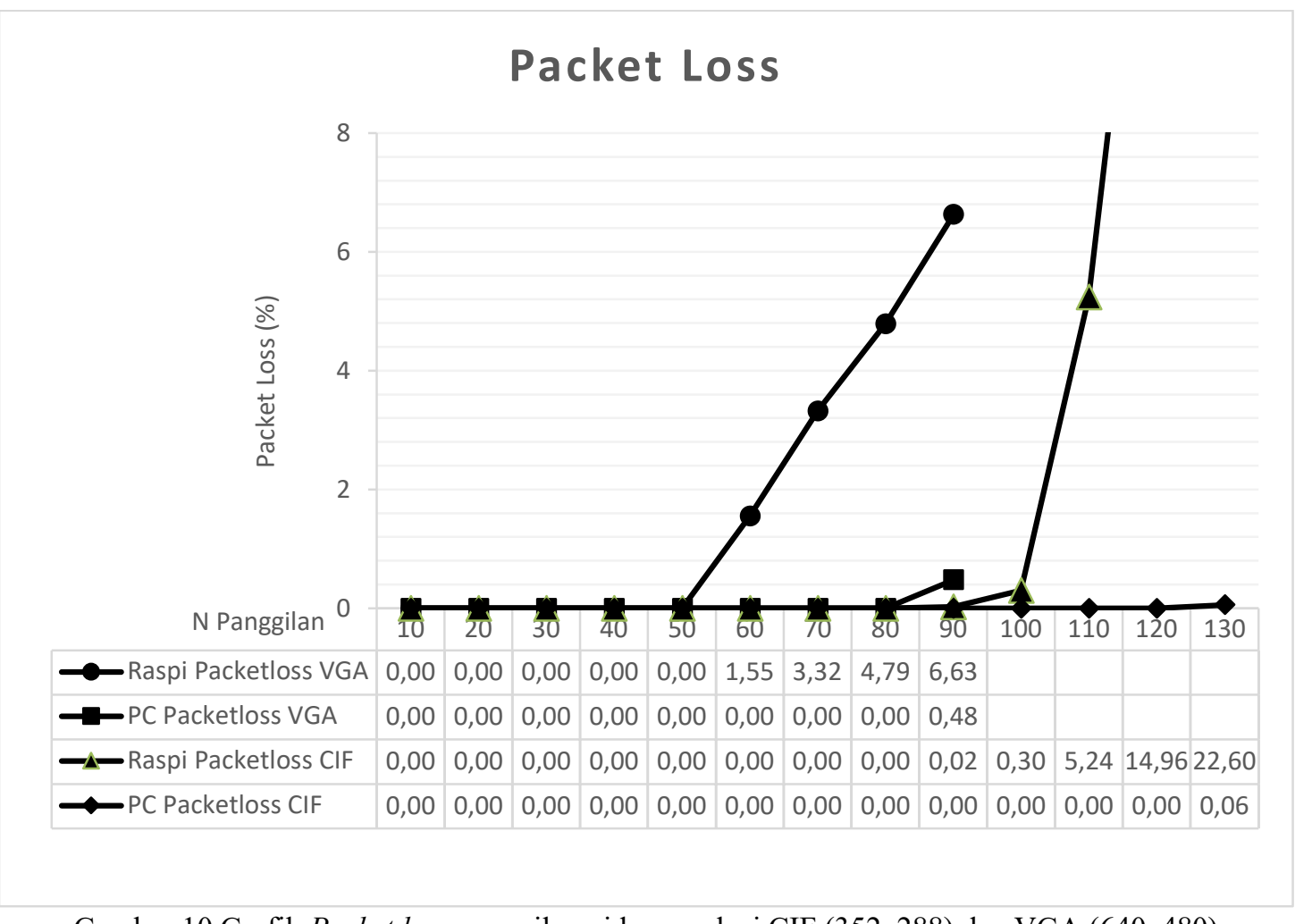

Gambar 10 Grafik Packet loss panggilan video resolusi CIF (352x288) dan VGA (640x480) 
Mean Opinion Score (MOS) merupakan ukuran yang paling umum digunakan untuk menentukan kualitas dari video call yang ditransmisikan. Hasil MOS panggilan video bersamaan dengan resolusi CIF (352x288) dan VGA (640x480) pada Raspberry Pi dan PC yang dijadikan server dapat dilihat pada Gambar 11 yang merupakan hasil penelitian.

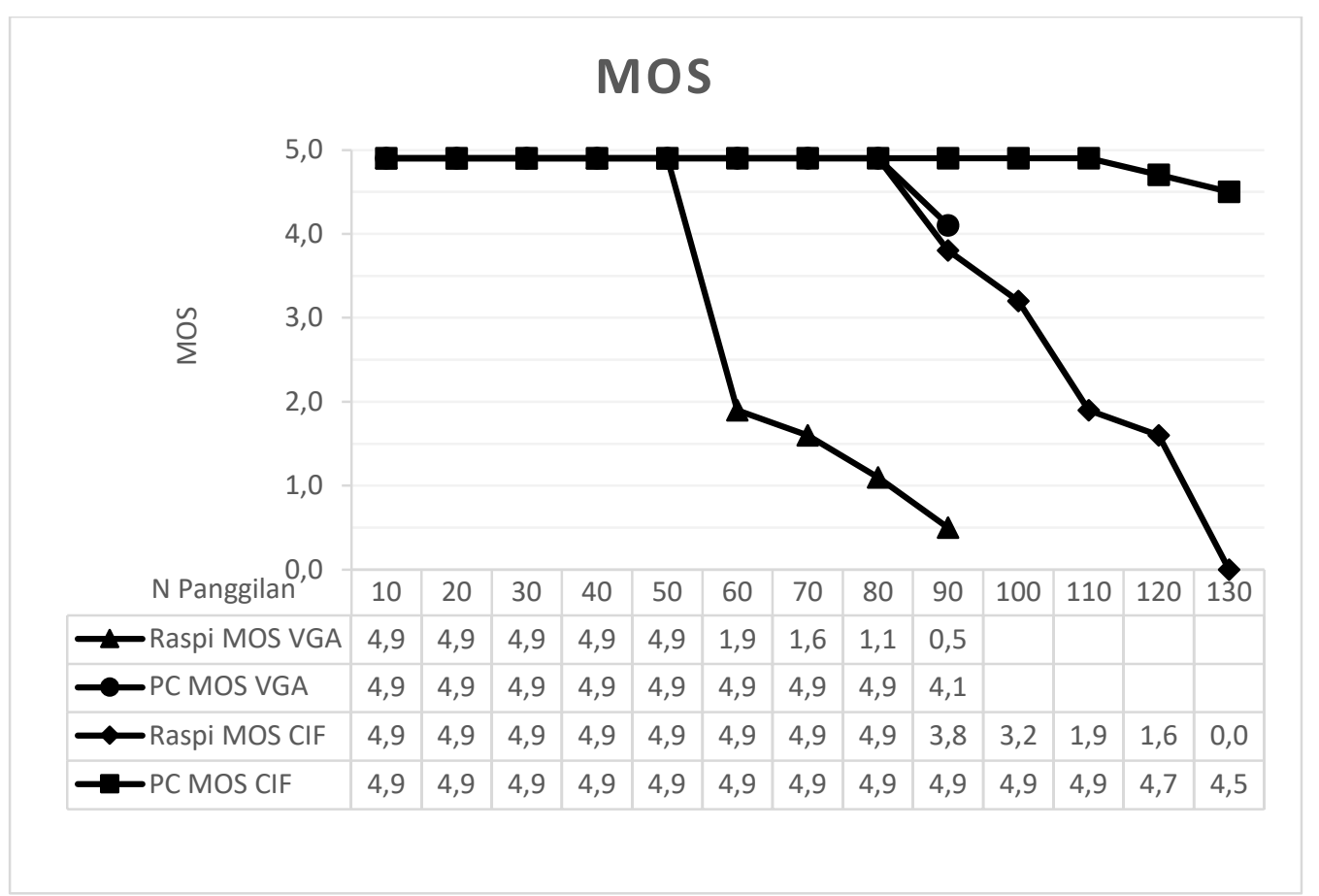

Gambar 11 Grafik MOS panggilan video resolusi CIF (352x288) dan VGA (640x480)

\section{KESIMPULAN DAN SARAN}

Berdasarkan hasil penelitian yang dilakukan oleh peneliti maka peneliti menarik kesimpulan bahwa dalam skala kecil Raspberry Pi mampu melayani komunikasi VVoIP dengan baik sehingga layak diimplementasikan sebagai SIP (Session Initiation Protocol) server dari aplikasi video phone, namun jika penggunaan skala yang lebih besar PC masih memiliki keunggulan lebih baik dari Raspberry Pi. Jumlah kedatangan panggilan perdetik yang mampu dilayani Raspberry Pi sebanyak 85 panggilan. Jika dibandingkan dengan PC yang mampu menangani panggilan perdetik sebanyak 233 panggilan, jumlah kedatangan panggilan perdetik yang mampu dilayani oleh Raspberry Pi jauh lebih kecil dibandingkan PC. Pada pengujian panggilan bersamaan dalam satu waktu. Raspberry Pi yang difungsikan sebagai SIP (Session Initiation Protocol) server mampu melayani hingga 131 panggilan video dengan resolusi CIF, 94 panggilan video dengan resolusi VGA. Akan tetapi dari segi kualitas video dan audio Raspberry Pi hanya mampu melayani 101 panggilan video dalam satu waktu dengan kualitas video dan audio yang tidak buruk untuk resolusi CIF (352x288) dam 53 panggilan untuk resolusi panggilan video VGA (640x480). Semakin banyak panggilan atau trafik VVoIP yang dilayani oleh server atau Raspberry Pi maka akan semakin menurun kualitas audio dan video dari komunikasi VVoIP yang melewati server. Ketika penggunaan processor telah mencapai atau mendekati $100 \%$ maka akan terjadi penurunan drastis kualitas video dan audio dari komunikasi VVoIP.

\section{DAFTAR PUSTAKA}

[1] M. Abdelmotalab, A. Suliman, A. Babiker, and N. Mustafa, "UMTS VoIP Codec QoS 
Evaluation," IEEE Int. Conf. Syst. Sci. Eng., vol. 10, no. 2, pp. 7-12, 2015.

[2] N. M. Edan, S. Turner, and A. Al-sherbaz, "Performance Evaluation of QoS Using SIP \& IAX2 VVoIP Protocols with CODECS," IEEE Int. Conf. Syst. Sci. Eng., pp. 631-636, 2016.

[3] A. Asiri and L. Sun, "Performance Analysis of Video Calls Using Skype," IEEE Int. Conf. Syst. Sci. Eng., pp. 155-162.

[4] M. Zasępa, P. Sȩkalski, B. Sakowicz, and P. Mazur, "Implementation of cost-effective VoIP network," Proc. 16th Int. Conf. - Mix. Des. Integr. Circuits Syst. Mix. 2009, pp. 159$162,2009$.

[5] A. Najihi, I. M. Wayan, Widyawan, and E. Najwaini, "Analisis Kinerja IP PBX Server pada Single Board Circuit Raspberry PI," J. POSITIF, Vol. I, No.2, Mei 201616 - 24, vol. I, no. 2, pp. 16-24, 2016.

[6] Prapanca, Aditya., 2015 Spesifikasi Raspberry Pi, if.unesa.ac.id, Available at: http://if.unes-a.ac.id/blog/aditya/2015/11/18/198/, Diakses 10 November 2019.

[7] E. Najwaini and A. Ashari, "Analisis Kinerja IP PBX Server pada Single Board Circuit Raspberry PI,” IJCCS, Vol.9, No.1, January 2015, pp. 89 100, vol. I, no. 2, pp. 16-24, 2015.

[8] E. B. Setiawan, "ANALISA QUALITY OF SERVICES ( QoS ) VOICE OVER INTERNET PROTOCOL ( VOIP ) DENGAN PROTOKOL H . 323 DAN SESSION INITIAL PROTOCOL ( SIP )," J. Ilm. Komput. dan Inform. ( KOMPUTA ), vol. I, no. 2, pp. 1-8, 2012.

[9] W. . Purnawan and Y. Rosita, "Rancang Bangun Smart Home System Menggunakan NodeMCU Esp8266 Berbasis Komunikasi Telegram," Techno.COM, vol. 18, no. 4, pp. 348-360, 2019.

[10] M. F. Wicaksono, "Implementasi Modul Wifi Nodemcu Esp8266 Untuk Smart Home," J. Tek. Komput. Unikom, vol. 6, no. 1, pp. 1-6, 2017. 